\section{Study of growth potential of Listeria monocytogenes in low fat salami: an innovative Italian meat product}

\author{
Elena Dalzini, Elena Cosciani-Cunico, \\ Enrico Pavoni, Barbara Bertasi, \\ Paolo Daminelli, Guido Finazzi, \\ Marina N. Losio, Giorgio Varisco \\ Laboratorio di Microbiologia degli \\ Alimenti, Istituto Zooprofilattico \\ Sperimentale della Lombardia \\ e dell'Emilia Romagna \\ B. Ubertini, Brescia, Italy
}

\section{Abstract}

In the last years, consequently to EC Regulation no. 1924/2006 on nutrition and health claims made on foods, some Italian food businnes operators (FBOs) leaders in the meat sector, invested in research to develop innovative products such as low fat salami, containing up to $30 \%$ less fat than the traditional one. For FB0s it is essential to demonstrate for each production process whether the substrate allows the growth of $L$. monocytogenes and whether $L$ monocytogenes could reach or exceed the limit of $100 \mathrm{cfu} \mathrm{g}^{-1}$ at the end of the shelf life, as stated by EC Regulation no. 2073/2005. In the present study, the growth potential of $L$. monocytogenes during the shelf life of low fat salami packed in modified atmosphere was evaluated. The results show that the product is unable to support the growth of pathogen, even if the storage temperature is between 8 and $12^{\circ} \mathrm{C}$.

\section{Introduction}

According to EC Regulation No. 1924/2006 (European Commission, 2006b) on nutrition and health claims made on foods, the food business operators (FBOs) must deliver health-oriented goods to the consumer. Following this regulation, some Italian company's leader in the meat sector invested to design innovative products: this is the case of low fat Salami, a cured salami that contains up to $30 \%$ less fat than the traditional one. The low fat Salami is a dry sausage traditionally manufactured using raw pork (meat and fat), salt and spices. It relies on a decrease of $\mathrm{pH}$ and water activity $\left(a_{w}\right)$ during fermentation and drying both for its quality and safety attributes. Foodborne pathogens, such as Listeria monocytogenes, may contaminate these products through raw meat, ingredients or processing equipment, and/or through post-processing contamination (Barbuti and Parolari, 2002). In fact, L. monocytogenes may survive or grow in products across a wide range of $\mathrm{pH}$ and $a_{w}$, even in the presence of nitrite and nitrate salts, and at refrigeration temperatures; they may also persist on contaminated surfaces of processing plants for long periods of time (Peccio et al., 2003; EUCRL, 2008). The slicing operation is one of the steps in preparing sliced ready-to-eat (RTE) meat products such as ham, salami, bologna, and other restructured meat available in the supermarket refrigerated food section. Slicing is an important stage to check for L. monocytogenes contamination, since it is the last processing step, without further thermal treatment, before consumption (Lin et al., 2006). Recently, particular attention has been paid in checking for $L$. monocytogenes in RTE meat products, such as salami, as a consequence of several listeriosis outbreaks that have occurred due to the consumption of these products (European Commission, 2005). After the publication of EC Regulation No. 2073/2005 amended by EC Regulation No. 1441/2007 (European Commission, 2005, 2007) the tolerance level of $100 \mathrm{cfu} \mathrm{g}^{-1}$ in some RTE meat products, including salami and fermented sausages, was introduced. Thus, for the first time, RTE foods were legislatively distinguished into those that support the growth of $L$. monocytogenes and those that do not support the growth of $L$. monocytogenes. Products with $\mathrm{pH} 4.4$ or $a_{w} 0.92$, products with $\mathrm{pH} 5.0$ and $a_{w} 0.94$ and products with a shelf-life of less than five days are automatically considered to belong to the category of RTE foods that do not support the growth of $L$. monocytogenes. The regulation also states that other categories of products can also belong to this category, subject to scientific justification. However, one of the limit is represented by the difficulty to find these studies both in literature or documents which actually are comparable with the product under study. For these reasons, the present study aims at evaluating the growth potential of $L$. monocytogenes during the shelf life of low fat salami, sliced and packed in modified atmosphere. This paper proposes to be a useful scientific tool for food manufacturers that produce RTE meat products with similar characteristics, to demonstrate whether their product supports the growth of $L$. monocytogenes or not, according to EC Regulation No. 2073/2005 (European Commission, 2005).

\section{Materials and Methods}

\section{Salami samples}

Low fat salami is an Hungarian style salami, made by minced pork meat and fat, supple-
Correspondence: Elena Dalzini, Laboratorio di Microbiologia degli Alimenti, Istituto Zooprofilattico Sperimentale della Lombardia e dell'Emilia Romagna B. Ubertini, via A. Bianchi 9, 25124 Brescia, Italy.

Tel. +39.030.2290611 - Fax: +39.030 .2290542$

E-mail: elena.dalzini@izsler.it

Key words: challenge test, listeria monocytogenes, growth potential, ready-to-eat meat product, low fat salami.

Conflict of interests: the authors declare no potential conflict of interests.

Acknowledgments: the authors are grateful to $\mathrm{Dr}$ Paola Monastero, Stefania Ducoli, (Department of Food Microbiology, IZSLER, Brescia, Italy) for scientific support and technical assistance.

Funding: this work was partially supported by the Italian Ministry of Health within the research project Setting up of biocompetition and decontamination methods to improve technological processes and food safety.

Received for publication: 11 November 2013. Revision received: 7 January 2014.

Accepted for publication: 16 January 2014.

This work is licensed under a Creative Commons Attribution 3.0 License (by-nc 3.0)

(C) Copyright E. Dalzini et al., 2014

Licensee PAGEPress, Italy

Italian Journal of Food Safety 2014; 3:2112

doi:10.4081/ijfs.2014.2112

mented with nitrite and nitrate salt $(0.03 \%$, resulting in $150 \mathrm{ppm}$ sodium nitrite and 150 ppm potassium nitrate) (European Commission, 2006a), lyophilised microbial cultures of Staphylococcus xylosus and Lactobacillus sakei at a concentration of $10^{6}$ cfu $\mathrm{g}^{-1}$, sodium chloride (3\%), a mixture of dextrose and sucrose (1.3\%), ascorbic acid, and flavouring. The diameter of low fat salami is ca. $18 \mathrm{~cm}$, while the length is ca. $40 \mathrm{~cm}$, the initial weight is approximately $4.7 \mathrm{~kg}$. The ripening of salami is carried out at $15^{\circ} \mathrm{C}$ for 20 days, to obtain a weight loss of $0.9 \mathrm{~kg}$. At the end of the process low fat salami is sliced and ca. $100 \mathrm{~g}$ of product are tray-packed in modified atmosphere $\left(30 \% \mathrm{CO}_{2}\right.$ and $\left.70 \% \mathrm{~N}_{2}\right)$. To simulate $L$. monocytogenes post-process contamination, three batches, obtained from a commercial processing plant, were used for this trial. Each batch was formed by 42 trays of sliced salami, packed in modified atmosphere.

\section{Bacterial cultures and inoculum preparation}

A multi-strain cocktail of $L$. monocytogenes (ATCC $^{\circledR} 19115^{\mathrm{TM}}, \mathrm{Lm} 46113$ and $\mathrm{Lm} 168619$ from the Istituto Zooprofilattico Sperimentale della 
Lombardia e dell'Emilia Romagna collection), was used in these experiments. Each stock cultures were kept frozen $\left(-80^{\circ} \mathrm{C}\right)$ in Brain Heart Infusion (BHI; Oxoid, Basingstoke, UK) supplemented with $20 \%$ glycerol, and were regenerated by transferring into $\mathrm{BHI}$ and incubating at $37^{\circ} \mathrm{C}$ for $24 \mathrm{~h}$. Aliquots of the activated cultures were transferred into a plastic tube (EuroClone, Milano, Italy) containing BHI and incubated at $8^{\circ} \mathrm{C}$ for $18-20 \mathrm{~h}$. The cultures were combined in equal quantity from each of the three strains at the same concentration ( $c a .7 \log \mathrm{cfu} \mathrm{g}^{-1}$ ). The multi-strain cocktail was centrifuged for $60 \mathrm{~min}$ at $4^{\circ} \mathrm{C}, 4000 \mathrm{rpm}$ and the supernatant fluids were immediately drawn off and discarded. The pellet was washed with sterile physiological solution $\left(\mathrm{H}_{2} \mathrm{O}\right.$ with $\left.0.9 \% \mathrm{NaCl}\right)$, centrifuged as previously described, re-suspended in sterile physiological solution and appropriately diluted. Counts were confirmed by serial decimal dilution and inoculation in Agar Listeria Ottaviani Agosti (ALOA; Microbiol Diagnostici, Cagliari, Italy) plates incubated at $37^{\circ} \mathrm{C}$ for $24-48 \mathrm{~h}$.

\section{Surface inoculation of sliced salami}

The trays of sliced salami were aseptically opened and the slices were inoculated on the top surface with $1 \% \mathrm{v} / \mathrm{wt}$ of the multi-strain cocktail of $L$. monocytogenes to a final concentration of ca. 1.5-2 log cfu g-1 (contaminated samples) or with $1 \% \mathrm{v} / \mathrm{wt}$ of the sterile physiological solution (control samples). The inoculum was distributed over the entire surface with a sterile L-shaped plastic cell spreader (Incofar, Modena, Italy). The trays were placed into a laminar-flow hood and kept for $5 \mathrm{~min}$ at room temperature $\left(22 \pm 2^{\circ} \mathrm{C}\right)$ to allow the bacteria to stick on the slices. The slices were then re-packed into sterile polyethylene bags in modified atmosphere $\left(30 \% \mathrm{CO}_{2}: 70 \% \mathrm{~N}_{2}\right)$ using S100-Tecnovac equipment [Tecnovac, Grassobbio (BG), Italy].

\section{Storage condition and sampling time}

The manufacturer has defined for the product a shelf life of 90 days. The packages of sliced salami were stored at $8^{\circ} \mathrm{C}$ for 7 days, and at $12^{\circ} \mathrm{C}$ for the remaining storage time $(83$ days) (EUCRL, 2008). All analyses were carried out with three technical replicates for each batch $(\mathrm{N}=3$ batch; $\mathrm{n}=3$ replicates per sampling time). Microbiological analysis was conducted for each batch using triplicate samples and duplicate plating of each dilution. Microbiological analyses were performed at 0 , $15,30,45,60,75$ and 90 days. Physical and chemical analyses were carried out at day 0 , just after the inoculum, and at day 90 , the end of the storage time.

\section{Microbiological and physicochemi- cal analysis}

For microbial analyses, the slices (100 g) were transferred into plastic one-chamber filter stomacher bags (NEOMED, London, UK) and homogenised 1:3 (wt:v) in sterile peptone water (PW) (CONDA, Madrid, Spain) for $3 \mathrm{~min}$ in a Stomacher 400 blender (Seward Medical, London, UK). Decimal dilutions in sterile PW were prepared from each bag. A quantitative analysis for $L$. monocytogenes enumeration was performed according to ISO 11290-2 (ISO, 1998). The pathogens plate count was performed also on control samples at time zero, to verify the natural meat contamination level. For the enumeration of lactic acid bacteria on control samples, the appropriate dilution was pour plating $(1 \mathrm{~mL})$ in de Man, Rogosa and Sharpe agar (MRS; Microbiol Diagnostici) and incubating in micro-aerophilic condition at $30^{\circ} \mathrm{C}$ for $48-72 \mathrm{~h}$.

Physical and chemical analyses were carried out at the beginning and at the end of shelf life on control samples. The $\mathrm{pH}$ values were measured using a HI 223 Calibration check $^{\mathrm{TM}}$ Microprocessor pH meter (Hanna Instrument, Smithfield, RI, USA) equipped with a Gel-Glass electrode (Hamilton, Switzerland). Water activity $\left(a_{w}\right)$ was measured at $25^{\circ} \mathrm{C}$ with the $a_{w}$ recorder AquaLab, series 3, Model TE (Decagon Devices Inc., Pullman, WA, USA) in accordance with ISO/FDIS 21807 (ISO/FDIS, 2004).

\section{Statistical analysis}

Counting results were expressed as colony forming unit (cfu) per gram. Microbial counts were reported in terms of $\log \mathrm{cfu} \mathrm{g}^{-1}$. The individual means and standard deviations of microbial counts and physicochemical values were determined from the average of three samples at each sampling time for each batch. The data were statistically analysed using $\mathrm{R}$ statistical software version 2.7.0 ( $R$ Development Core Team, 2008). The differences between mean values were detected by the HSD Tukey's test and evaluations were based on a confidence interval of $95 \%$.

To determine the growth potential of $L$. monocytogenes it is recommended to calculate the difference between the median concentration at the end of shelf life (day 90) and the median concentration at the beginning of the shelf life (day 0 ), in three replicates, for three batches (EUCRL, 2008).

\section{Results}

To evaluate the intrinsic properties of low fat salami, for all three batches, $\mathrm{pH}$ and $a_{w}$ were measured (Table 1) in control samples. At the beginning of the shelf life, the average values of $\mathrm{pH}$ and $a_{w}$ in sliced salami was $5.00 \pm 0.10$ (range 4.82-5.11) and 0.945 \pm 0.005 (range 0.936-0.951) respectively. At the end of the shelf life, no statistical difference $(\mathrm{P}>0.05)$ was observed for $\mathrm{pH}$ average. The $a_{w}$ decreased $(\mathrm{P}<0.05)$ to $0.939 \pm 0.003$ (range 0.935-0.949) at the end of shelf life.

To evaluate the background microbiota, the populations of lactic acid bacteria during the shelf life were investigated (Table 2). The average of lactic acid bacteria count decreased $(\mathrm{P}<0.05)$ from $7.85 \pm 0.20 \log _{\text {cfu }} \mathrm{g}^{-1}$ (range 7.44-8.14 $\log \mathrm{cfu} \mathrm{g}^{1}$ ) to $7.43 \pm 0.15 \log \mathrm{cfu} \mathrm{g}^{-1}$ (range 7.17-7.6) during the shelf life of sliced salami stored at low temperatures. Direct plating of control samples revealed $L$. monocytogenes absence $\left(<0.47 \log \mathrm{cfu} \mathrm{g}^{-1}\right)$ (data not shown).

The averages of pathogen count, in contaminated samples, are shown in Table 2. During the shelf life of sliced salami, L. monocytogenes artificially inoculated had decreased to below the level of detection $\left(<0.47 \log \mathrm{cfu} \mathrm{g}^{-1}\right)$. At day 0 the median concentration of $L$. monocytogenes was $1.77 \log \mathrm{cfu} \mathrm{g}^{-1}$ (range 1.77-1.83 log cfu g $^{-1}$ ), $1.38 \log$ cfu g $^{-1}$ (range 1.25-1.68 $\log$ $\mathrm{cfu} \mathrm{g}^{-1}$ ) and $1.65 \mathrm{log} \mathrm{cfu} \mathrm{g}^{-1}$ (range 1.51-1.77 $\log \mathrm{cfu}^{-1}$ ) for batch 1,2 and 3 respectively. The standard deviations between the three results at day 0 was less than $0.3 \log \mathrm{cfu} \mathrm{g}^{-1}$

Table 1. Average of $\mathrm{pH}$ and $\mathrm{a}_{\mathrm{w}}$ values of salami sliced at the beginning (day 0 ) and at the end (day 90) of the shelf life. Values are means \pm standard deviation of three replicates samples for each batch.

\begin{tabular}{ccc} 
Parameter & \multicolumn{2}{c}{ Shelf life (days) } \\
pH & 0 & 90 \\
Batch 1 & $4.87 \pm 0.04^{\mathrm{aA}}$ & $4.87 \pm 0.03^{\mathrm{aA}}$ \\
Batch 2 & $5.09 \pm 0.02^{\mathrm{bA}}$ & $5.14 \pm 0.02^{\mathrm{bB}}$ \\
Batch 3 & $5.05 \pm 0.05^{\mathrm{bA}}$ & $5.00 \pm 0.04^{\mathrm{cA}}$ \\
$a_{w}$ & & \\
Batch 1 & $0.939 \pm 0.005^{\mathrm{aA}}$ & $0.944 \pm 0.003^{\mathrm{aA}}$ \\
Batch 2 & $0.947 \pm 0.001^{\mathrm{BA}}$ & $0.936 \pm 0.001^{\mathrm{bB}}$ \\
Batch 3 & $0.950 \pm 0.001^{\mathrm{bA}}$ & $0.940 \pm 0.00^{2 \mathrm{bB}}$ \\
\hline
\end{tabular}

${ }_{a, b}$ Means with different lowercase letters within a column for each parameter are significantly different $(\mathrm{P}<0.05) ; \mathrm{A}, \mathrm{B}$ means with different uppercase letters within a row for each parameter are significantly different $(\mathrm{P}<0.05)$. 
Table 2. Average of lactic acid bacteria and L. monocytogenes counts of sliced salami during the shelf life. Values are means log cfu $\mathrm{g}^{-1} \pm$ standard deviation of three replicates samples for each batch.

\begin{tabular}{|c|c|c|c|c|c|c|c|}
\hline \multirow{2}{*}{ Organism $\left(\log \mathrm{cfu} \mathrm{g}^{-1}\right)$} & \multicolumn{7}{|c|}{ Shelf life (days) } \\
\hline & 0 & 15 & 30 & 45 & 60 & 75 & 90 \\
\hline \multicolumn{8}{|l|}{ Lab } \\
\hline Batch 1 & $7.91 \pm 0.11^{\mathrm{aA}}$ & $7.22 \pm 0.15^{\mathrm{a} B}$ & $7.63 \pm 0.22^{\mathrm{aAB}}$ & $7.44 \pm 0.15^{\mathrm{aAB}}$ & $7.19 \pm 0.30^{\mathrm{aAB}}$ & $7.38 \pm 0.22^{\mathrm{aAB}}$ & $7.34 \pm 0.12^{\mathrm{aAB}}$ \\
\hline Batch 2 & $7.84 \pm 0.14^{\mathrm{aA}}$ & $7.78 \pm 0.29^{\mathrm{bA}}$ & $7.60 \pm 0.09^{\mathrm{aA}}$ & $7.36 \pm 0.30^{\mathrm{aAB}}$ & $7.54 \pm 0.37^{\mathrm{aA}}$ & $8.06 \pm 0.06^{\mathrm{bAC}}$ & $7.54 \pm 0.05^{\mathrm{aA}}$ \\
\hline Batch 3 & $7.81 \pm 0.35^{\mathrm{aA}}$ & $7.58 \pm 0.15^{\mathrm{abA}}$ & $7.04 \pm 0.21^{\mathrm{bA}}$ & $7.35 \pm 0.60^{\mathrm{aA}}$ & $7.48 \pm 0.08^{\mathrm{aA}}$ & $7.10 \pm 0.33^{\mathrm{aA}}$ & $7.42 \pm 0.21^{\mathrm{aA}}$ \\
\hline \multicolumn{8}{|l|}{$\mathrm{Lm}$} \\
\hline Batch 1 & $1.79 \pm 0.03^{\mathrm{aA}}$ & $1.54 \pm 0.20^{\mathrm{aA}}$ & $1.20 \pm 0.08^{\mathrm{aB}}$ & $1.07 \pm 0.00^{\mathrm{aB}}$ & ND & ND & ND \\
\hline Batch 2 & $1.44 \pm 0.22^{\mathrm{aA}}$ & $1.31 \pm 0.21^{\mathrm{aA}}$ & $1.46 \pm 0.09^{\mathrm{aA}}$ & $1.66 \pm 0.06^{\mathrm{aA}}$ & ND & ND & ND \\
\hline Batch 3 & $1.64 \pm 0.13^{\mathrm{aA}}$ & $1.47 \pm 0.0^{6 \mathrm{aA}}$ & $1.39 \pm 0.22^{\mathrm{aA}}$ & $0.97 \pm 0.17^{\mathrm{bB}}$ & ND & ND & ND \\
\hline
\end{tabular}

Lab, lactic acid bacteria; Lm, L. monocytogenes; ND, not detected by either direct plating. ${ }^{a, b}$ Means with different lowercase letters within a column for each organism are significantly different (P<0.05); ${ }^{\text {A-C }}$ means with different uppercase letters within a row for each organism are significantly different $(\mathrm{P}<0.05)$.

(batch 1, $0.03 \log$ cfu g $^{-1}$; batch 2, $0.22 \log$ cfu $\mathrm{g}^{-1}$; batch 3, $0.13 \log \mathrm{cfu} \mathrm{g}^{-1}$ ) in compliance with technical guidance (EUCRL, 2008). The growth potential of $L$. monocytogenes was -1.30 $\log$ cfu g $^{-1}$ in batch 1, $-0.91 \log$ cfu g $^{-1}$ in batch 2 and $-1.18 \log$ cfu g $^{-1}$ in batch 3 .

\section{Discussion}

The prevalence and level of $L$. monocytogenes in RTE meat products, in which can survive for long periods are well documented (Gianfransceschi et al., 2006). In agreement with Vorst et al. (2006) post-processing manipulation, such as slicing and packaging of RTE meat products can enable cross-contamination and serve as a vector for the spread of pathogenic bacteria. Thus, to evaluate the growth potential of $L$. monocytogenes in low fat salami, a microbiological challenge test was carried out. A mixed inoculum of at least three strains is issued in standard microbial challenge protocol (EUCRL, 2008).

By comparing the results obtained from the analysis of the three batches, an interbatch variability of the physicochemical properties should be noted (Table 1). At the beginning of the shelf life, the physicochemical properties of batch 1 were statistically different from those of batches 2 and 3 ; this can be explained by the heterogeneity of the food products: differences in the intrinsic factors of the food product are inevitable. However, no difference was detected in the concentration of LAB and L. monocytogenes measured in the same batches at the beginning of shelf life (Table 2).

The results illustrate the importance of analysing various replicates per batch and of using several batches per product, in order to establish the inherent variability in growth potential linked to the product and its processing or storage conditions, as recommended by Annex II on challenge testing of EC Regulation 2073/2005 (European Commission, 2005) and in agreement with Vermeulen et al. (2011).
The physicochemical and microbiological properties of sliced salami investigated in this study are in agreement with those obtained by other authors (Aquilanti et al., 2007) in similar products. Otherwise, the physicochemical properties of salami $\left(\mathrm{pH} 5.00 \pm 0.10\right.$ and $a_{w}$ $0.945 \pm 0.005$ ) are not sufficient to justify the pathogen inactivation. In fact, it is already proved that $L$. monocytogenes is able to survive in environments with $\mathrm{pH}$ and $a_{w}$ values lower than those found in this study (Ross et al., 2000). Many studies show that the inactivation of $L$. monocytogenes could be explained by different factors, such as reductions of $\mathrm{pH}$ (Cole et al., 1990) and $a_{w}$ (Glass and Doyle, 1991; Sabatakou et al., 2001), addition of nitrite (Nyachuba et al., 2007; Kouakou et al., 2009) and packaging in modified atmosphere (MAP) (Marshall et al., 1992; Sørheim et al., 2004). Even the indigenous microbiota of RTE meat products could affect the behaviour of $L$. monocytogenes (Devlieghere et al., 2001; Mellefont and Ross, 2007). In agreement with this study, low level of $L$. monocytogenes is inactivated in presence of high concentration of lactic acid bacteria (Cornu et al., 2011). Therefore, even the use of Lactobacillus sakei strain as a starter culture in fermented sausages (such as in low fat salami) increased the inactivation of L. monocytogenes, as Drosinos et al. (2006) reported. Otherwise, following the hurdle technology concept, the present study demonstrates that the combination of all these factors is crucial and needed for food stability and safety (Leistner, 2000).

Considering the results of the present study it is possible to establish that sliced low fat salami belongs to the category of RTE foods unable to support the growth of $L$. monocytogenes in compliance with the EC Regulation No 2073/2005 (European Commission, 2005). In fact, even if the values of $\mathrm{pH}$ and $a_{w}$ and the storage temperature $\left(8-12^{\circ} \mathrm{C}\right)$ of low fat salami would allow the development of $L$. monocytogenes, this does not occur. This result indicates that the high concentration of lactic acid bac- teria at the time of contamination (manipulation post-process) and the modified atmosphere packaging combine to inhibit the development of $L$. monocytogenes, even if the EC Regulation No. 2073/2005 (European Commission, 2005) considers only the parameters $\mathrm{pH}$ and $a_{w}$ to determine if the product is able or unable to support the growth of the pathogen. In literature there are several papers that assess the growth potential of $L$. monocytogenes in fresh sauces for pasta (Grassi et al., 2013), mixed salads (Skalina and Nikolajeva, 2010) and vegetables (Sant'Ana et al., 2012), while studies conducted during the shelf life of Italian salami are not reported.

\section{Conclusions}

Collection and analysis of industry surveys and challenge studies will help to identify risk factors for contamination, and the impact of generic formulations on limiting the growth of L. monocytogenes in both traditional and proposed new RTE foods. Any information arising from challenge studies is encouraged for the industry use as whole, but especially for the smaller industry or artisanal producers. More food surveys and challenge studies are encouraged by regional/national authorities through government. This may be particularly important for artisanal products that have little or no challenge study data. The larger food companies conduct most challenge studies, and usually claim that the information is confidential; one reason is that the formulation would have to be declared. One approach would be to declare the food tested to be anonymous and perhaps reference classes of product rather than specific product items. Since food safety is seen as a non-competitive aspect of food production, industry representatives should explore ways with international bodies such as FA0, so that their research and survey data can be put in the public domain in a way that is 
useful to other manufacturers and governments but does not compromise privacy issues and legal obligations (Luber et al., 2011). Then, the presented data are currently needed, given the lack of similar information in the literature and could be considered as guidance for producers willing to perform challenge tests on their products. In fact, our findings are a useful tool for FBOs that produce RTE similar to validate the shelf life against $L$. monocytogenes according to Reg 2073/2005.

\section{References}

Aquilanti L, Santarelli S, Silvestri G, Osimani A, Petruzzelli A, Clementi F, 2007. The microbial ecology of a typical Italian salami during its natural fermentation. Int $\mathrm{J}$ Food Microbiol 120:136-45.

Barbuti S, Parolari G, 2002. Validation of manufacturing process to control pathogenic bacteria in typical dry fermented product. Meat Sci 62:323-9.

Cole M, Jones M, Holyoak C, 1990. The effect of $\mathrm{pH}$, salt concentration and temperature on the survival and growth of Listeria monocytogenes. J Appl Bacteriol 69:63-72.

Cornu M, Billoir E, Bergis H, Beaufort A, Zuliani V, 2011. Modeling microbial competition in food: Application to the behavior of Listeria monocytogenes and lactic acid flora in pork meat products. Food Microbiol 28:639-47.

Devlieghere F, Geeraerd AH, Versyck KJ, Vandewaetere B, Van Impe J, Debevere J, 2001. Growth of Listeria monocytogenes in modified atmosphere packed cooked meat products: a predictive model. Food Microbiol 18:53-66.

Drosinos EH, Mataragas M, VeskovicMoracanin S, Gasparik-Reichardt J, Hadziosmanovic M, Alagic D, 2006. Quantifying nonthermal inactivation of Listeria monocytogenes in European fermented sausages using bacteriocinogenic lactic acid bacteria or their bacteriocins: a case study for risk assessment. J Food Prot 69:2648-63.

European Commission, 2005. Regulation of the European Parliament and of the Council of 15 November 2005 on microbiological criteria for foodstuffs, 2073/2005/CE. In: Official Journal, L 338, pp. 1-26.

European Commission, 2006a. Directive of the European Parliament and of the Council of 5 July 2006 amending Directive 95/2/EC on food additives other than colours and sweeteners and Directive $95 / 35 / \mathrm{EC}$ on sweeteners for use in foodstuffs, 2006/52/EC. In: Official Journal, L 204, 26 7-2006.
European Commission, 2006b. Regulation of the European Parliament and of the Council of 20 December 2006 on nutrition and health claims made on foods, 1924/2006/CE. In: Official Journal, L 404, pp. 9-25.

European Commission, 2007. Regulation of the European Parliament and of the Council of 5 December 2007 amending Regulation (EC) No 2073/2005 on microbiological criteria for foodstuffs, 1441/2007/EC. In: Official Journal, L 322, pp. 12-29.

EUCRL, 2008. Technical guidance document on shelf-life studies for Listeria monocytogenes in ready-to-eat foods. European Union Community Reference Laboratory for Listeria monocytogenes, French Food Safety Agency ed., Maisons-Alfort, France.

Gianfransceschi M, Gattuso A, Fiore A, D'Ottavio MC, Casale M, Palumbo A, Aureli P, 2006. Survival of Listeria monocytogenes in uncooked Italian dry sausage (salami). J Food Prot 69:1533-8.

Glass KA, Doyle MP, 1991. Relationship between water activity of fresh pasta and toxin production by proteolytic Clostridium botulinum. J Food Prot 54:1625.

Grassi MA, Nucera D, Lomonaco S, Civera T, 2013. Growth potential of Listeria monocytogenes in fresh sauces for pasta. Food Control 30:288-91.

ISO, 1998. Microbiology of food and animal feeding stuffs. Horizontal method for the detection and enumeration of Listeria monocytogenes. Part 2: Enumeration method. ISO Norm 11290-2:1998. International Standardization Organization ed., Geneva, Switzerland.

ISO/FDIS, 2004. Microbiology of food and animal feeding stuffs-determination of water activity. ISO/FDIS 21807:2004. International Organization for Standardization, Geneve, Switzerland.

Kouakou P, Ghalfi H, Destain J, DuboisDauphin R, Evrard P, Thonart P, 2009. Effects of curing sodium nitrite additive and natural meat fat on growth control of Listeria monocytogenes by the bacteriocin-producing Lactobacillus curvatus strain CWBI-B28. Food Microbiol 26:623-8.

Leistner L, 2000. Basic aspects of food preservation by hurdle technology. Int $\mathrm{J}$ Food Microbiol 55:181-6.

Lin C, Takeuchi K, Zhang L, Dohm CB, Meyer JD, Hall PA, Doyle MP, 2006. Cross contamination between processing equipment and deli meats by Listeria monocytogenes. J Food Prot 69:71-9.

Luber P, Crerar S, Dufour C, Farber J, Datta A, Todd ECD, 2011. Controlling Listeria monocytogenes in ready-to-eat foods: working towards global scientific consen- sus and harmonization - Recommendations for improved prevention and control. Food Control 22:1535-49.

Marshall DL, Andrews LS, Wells JH, Farr AJ, 1992. Influence of modified atmosphere packaging on the competitive growth of Listeria monocytogenes and Pseudomonas fluorescens on precooked chicken. Food Microbiol 9:303-9.

Mellefont LA, Ross T, 2007. Effect of potassium lactate and a potassium lactate-sodium diacetate blend on Listeria monocytogenes growth in modified atmosphere packaged sliced ham. J Food Prot 70:2297-305.

Nyachuba DG, Donnelly CW, Howard AB, 2007. Impact of nitrite on detection of Listeria monocytogenes in selected ready-to-eat (RTE) meat and seafood products. J Food Sci 72:267-75.

Peccio A, Autio T, Korkeala H, Rosmini R, Trevisani M, 2003. Listeria monocytogenes occurrence and characterization in meatproducing plants. Lett Appl Microbiol 37:234-8.

R Development Core Team, 2008. R: a language and environment for statistical computing. R Foundation for Statistical Computing, Vienna, Austria.

Ross T, Dalgaard P, Tienungoon S, 2000. Predictive modelling of the growth and survival of Listeria in fishery products. Int J Food Microbiol 62:231-45.

Sabatakou 0, Watsos E, Mantis F, Ramantanis $\mathrm{S}, 2001$. Classification of Greek meat products on the basis of $\mathrm{pH}$ and $\mathrm{a}_{\mathrm{w}}$ values. Fleischwirtschaft Int 2:92-6.

Sant'Ana AS, Barbosa MS, Destro MT, Landgraf M, Franco BDGM, 2012. Growth potential of Salmonella spp. and Listeria monocytogenes in nine types of ready-to-eat vegetables stored at variable temperature conditions during shelf-life. Int J Food Microbiol 157:52-8.

Skalina L, Nikolajeva V, 2010. Growth potential of Listeria monocytogenes strains in mixed ready-to-eat salads. Int $\mathrm{J}$ Food Microbiol 144:317-21.

Sørheim 0, Ofstad R, Lea P, 2004. Effect of carbon dioxide on yield, texture and microstructure of cooked ground beef. Meat Sci 67:231-6.

Vermeulen A, Devlieghere F, De Loy-Hendrickx A, Uyttendaele M, 2011. Critical evaluation of the EU-technical guidance on shelf-life studies for L. monocytogenes on RTEfoods: a case study for smoked salmon. Int J Food Microbiol 145:176-85.

Vorst KL, Todd ECD, Ryser ET, 2006. Transfer of Listeria monocytogenes during mechanical slicing of turkey breast, bologna, and salami. J Food Prot 69:619-26. 